\title{
Studies on water pollution due to toxic metals in Ulhas River flowing along the Dombivli City of Mumbai, India
}

\author{
Amol M. Jadhav ${ }^{1}$, Pravin U. Singare ${ }^{2 *}$ \\ ${ }^{1}$ Research Scholar, Department of Chemistry, Shri. Jagdishprasad Jhabarmal Tibrewala \\ University, Jhunjhunu, \\ Rajasthan 333001, India \\ ${ }^{2}$ Department of Chemistry, Bhavan's College, Munshi Nagar, Andheri (West), Mumbai 400058, \\ India \\ *Corresponding author e-mail: pravinsingare@gmail.com
}

Keywords: Ulhas River; heavy metals; water; industrial pollution; Dombivli; Mumbai.

\begin{abstract}
Dombivli city is one of the most industrialized cities situated near Mumbai. The increase in industries, has led to increase in the discharge of industrial waste effluents from the industrial belt into the Ulhas River, due to improper environmental planning. This day by day increasing tremendous pollution load has prompted us to carry the systematic and detailed study on the heavy metal content in water of Ulhas River. The study was conducted over a period of two years i.e. in 2012 and 2013. The study was carried out along the banks of Ulhas River, near the discharge of effluents from Dombivli Industrial belt Phase I and Phase II. The sampling points were identified accordingly. The analysis for the majority of the toxic heavy metals like Mercury $(\mathrm{Hg})$, Arsenic (As), Cadmium (Cd), Cobalt (Co), Lead ( $\mathrm{Pb}$ ), Nickel ( $\mathrm{Ni})$, Chromium $(\mathrm{Cr})$, Copper $(\mathrm{Cu})$, Zinc $(\mathrm{Zn})$ and Iron $(\mathrm{Fe})$ in water samples was done. The results of our study indicated that there is a need to conduct systematic and regular monitoring of pollution level along the Ulhas River with an intention to obtain the scientific data on heavy metal content in the river water. Such data will be useful to improve the industrial waste treatment technology adopted along the Dombivli industrial belt.
\end{abstract}

\section{INTRODUCTION}

The industrial sector in India has grown tremendously. However, this has resulted to an increase in air, water and soil pollution. Discharge of large amount of industrial waste, which includes various toxic heavy metals, toxic chemicals, carcinogens, pesticides and many other chemicals from a variety of industries, are added to the water bodies. This has significantly impacted the quality of water in comparison to the international standards. It is found that almost all rivers are polluted in most of the stretches by some industry or the other [1]. Though all industries in India function under the strict guidelines of the Central Pollution Control Board (CPCB), however still the environmental situation is far from satisfactory. Many of the major industries have facilities for the treatment of generated waste. However, in the case of small scale industries, since they have lower profit margins, they do not afford huge investment for pollution control facilities. Thus in India, there are sufficient evidences available related with the mismanagement of industrial wastes [2-7]. The problem of water pollution has become still worse due to toxic heavy metals. Untreated or allegedly treated industrial effluents and sewage water contains variable amounts of heavy metals such as arsenic, mercury, cadmium, lead, nickel, copper, chromium and zinc [6-8]. The excess of these heavy metals lead to number of disorders [9].The aquatic flora and fauna is significantly affected by the presence of these heavy metals. They enter the food chain through biomagnification and eventually affect human beings. India is one of the identified hotspots of $\mathrm{Hg}$ pollution in the world [10]. Studies highlight that the aquatic ecosystem in India has significant amount of $\mathrm{Hg}$ [11-13]. The toxic heavy metals in aquatic environment are adsorbed onto particulate matter, although they can form free metal ions and soluble complexes that are available for uptake by biological organisms [14]. The metals associated with particulate material are also available for biological uptake [15] and are deposited in estuarine sediments [16]. Once deposited, binding by sulfides and/or iron hydroxides immobilizes trace metals until a change in redox or $\mathrm{pH}$ occurs [17, 
18]. Thus, in surfical sediments, especially in the fine fraction, trace metals are accumulated and provides a means for evaluating the long term accumulation of contaminants $[6,19]$. Hence there is a need for extensive monitoring of pollution along the different water bodies, over a long period of time, to describe average metal precipitation [20] and the precipitation trend, which forms an important component of pollution control management. Ulhas River is one of the important water bodies in Thane District of Maharashtra State. The effluent water from the nearby industrial belt of Dombivli city contributes the largest source of heavy metal concentration in the river. The discharge of heavy metal wastes into receiving waters may result in numerous physical, chemical, and biological disorders [21]. As per the Maharashtra Pollution Control Board (MPCB), the main sources of river water pollution, are the occasional discharge of untreated sewage and industrial effluent in rivers across the state. The pollution data of water bodies due to discharge of industrial waste [6,7,22-29] points out the need of systematic and regular monitoring of pollution level for further improvement in the industrial waste water treatment methods. We therefore, initiated a study to understand the heavy metals content in the water of Ulhas River along the Dombivli city, situated near Mumbai, India. The experimental data will help in understanding the effectiveness of pollution control measures already is existence, the extent of pollution control needed and the rational planning and prioritization of pollution control strategies.

\section{Materials and methods}

\subsection{Area of study}

The study was carried out along the banks of Ulhas River near the discharge of industrial effluents released from Dombivli Maharashtra Industrial Development Corporation (MIDC) Industrial belt Phase I and Phase II. In 1964, the Dombivli industrial area was established by M.I.D.C. The industrial belt occupies an area of about 347.88 hector, is located in south of Ulhas River. There are many small/ medium/ large scale agrochemicals, fine chemicals, dyes manufacturing, textile, engineering, pharmaceutical, metallurgical and paint manufacturing industries located in this industrial belt, which are contributing heavy pollution in the surrounding area [30-38]. About 14 MLD of industrial effluent is generated from the industrial area which is regularly discharged through open drainages into the nearby flowing Ulhas River [39]. In figure 1, D1 and D2 represent the locations at which the effluent water from the Dombivali Industrial belt is regularly discharged in to the Ulhas River. Following sampling locations were identified:

Sampling Point S1: Before the discharge of effluent from Dombivli MIDC Phase I.

Sampling Point S2: After the discharge of effluent from Dombivli MIDC Phase 1.

Sampling Point S3: After the discharge of effluent from Dombivli MIDC Phase II.

Sampling Point S4: After the discharge of effluent from Dombivli MIDC Phase II.

The above sampling locations are as shown in Figure 1.

\subsection{Climatic conditions}

Dombivli enjoys a tropical climate with mean annual temperature of $24.3{ }^{\circ} \mathrm{C}$ (min) to $32.9{ }^{\circ} \mathrm{C}$ $(\max )$. The hottest and driest part of the year is April-May, when temperature rises to $38.0{ }^{\circ} \mathrm{C}$. The humidity is usually in the range of 58 to $84 \%$ and sea breeze in the evening hours is a blessing to combat the high temperature and humidity during summer months. The average southwest monsoon rainfall is in the range of $1850 \mathrm{~mm}$ to $2000 \mathrm{~mm}$. The average annual rainfall in the region is the range from 1286 to $1233 \mathrm{~mm}$ [39]. 


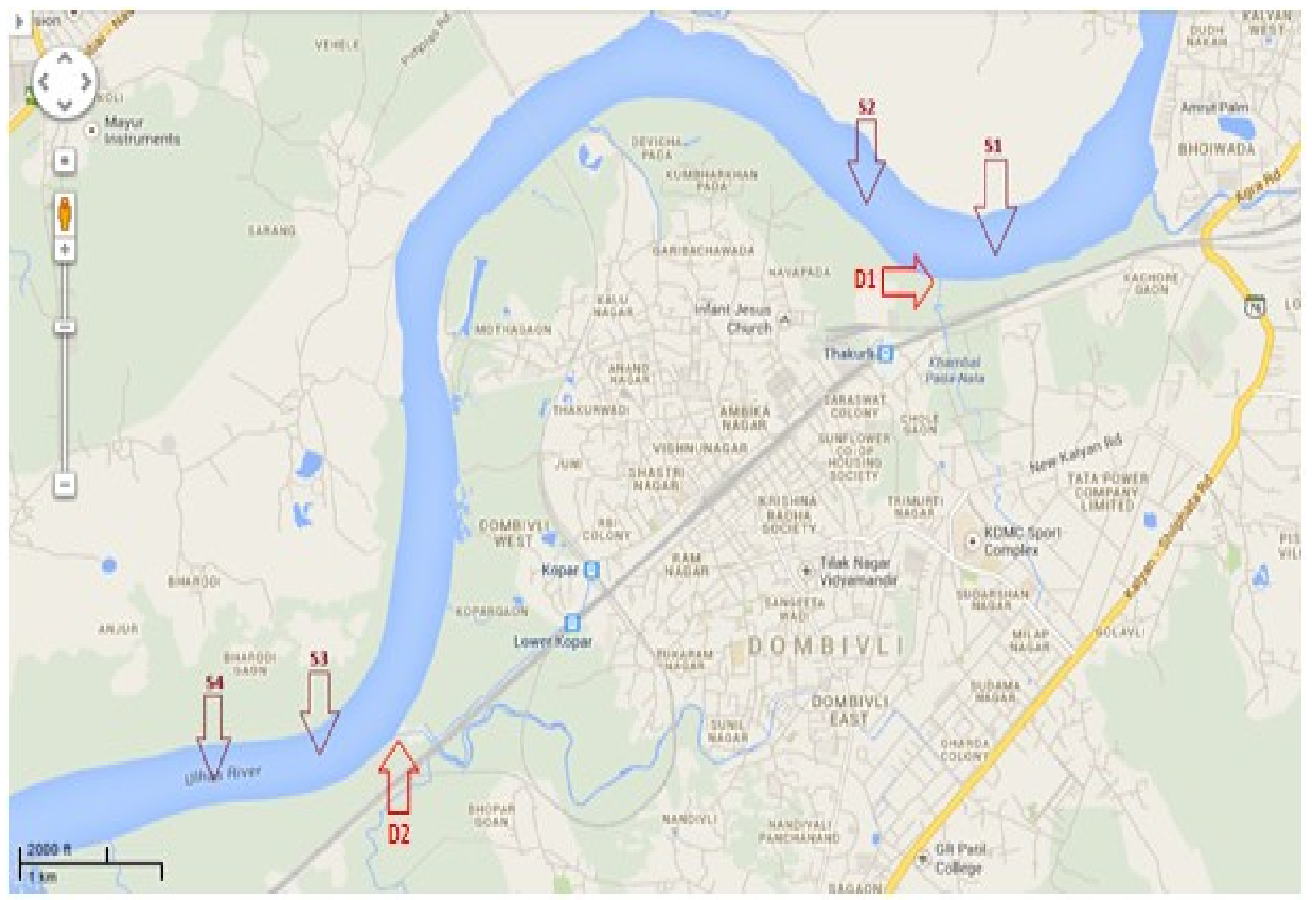

Figure1: Effluent discharge locations (D) and sampling locations (S) in Ulhas River along Dombivli City.

\subsection{Sample planning, collection and preservation}

The study on pollution status along the Ulhas River was carried out for two years 2012 and 2013. The sampling of water was done every week along identified locations of the Ulhas River along Dombivli city. This was done for all the three seasons - summer, rainy and winter for a period of twenty four months. The water samples collected from different sampling stations were filtered using Whatman No. 41 (pore size $0.45 \mu \mathrm{m}$ ) filter paper to remove suspended particles. The filtrate was preserved in polythene bottles. $2 \mathrm{~mL}$ nitric acid was added to the filtrate to prevent metal precipitation. On a waterbath, the water samples were concentrated to tenfolds followed by subjecting to nitric acid digestion. After evaporation to near dryness, the samples were dissolved in $2 \%$ nitric acid, filtered and then diluted to $50 \mathrm{~mL}$ with distilled water [40-45]. The treated samples were analyzed for the majority of the toxic metals like mercury $(H g)$, arsenic $(A s)$, cadmium $(C d)$, cobalt $(\mathrm{Co})$, lead $(\mathrm{Pb})$, nickel $(\mathrm{Ni})$, chromium $(\mathrm{Cr})$, copper $(\mathrm{Cu})$, zinc $(\mathrm{Zn})$ and iron $(\mathrm{Fe})$ by Flame Atomic Absorption Spectrophotometer. For estimation of arsenic (As) and mercury $(\mathrm{Hg})$, hydride generation coupled with an atomic fluorescence detector and cold-vapor techniques were used respectively [43]. The techniques and methods followed for analysis and interpretation were according to the standard procedures [23-25, 38, 41-45].

\subsection{Quality Assurance}

Analytical reagent grade chemicals and reagents were used for analysis. All reagents were standardized against primary standards to determine their actual concentrations. Reagent blanks were used in analysis to correct the interference of reagent impurities and other environmental contaminations. All calibrated instruments were used for analysis. The relevant laboratory apparatus were soaked in nitric acid before analysis followed by rinsing thoroughly with potable water followed by deionised water to ensure that all traces of cleaning reagents are removed. The pipettes and burette were rinsed with the experimental solution before final use. 


\subsection{Heavy metal analysis by AAS technique}

The analysis for the majority of the toxic heavy metals like Mercury ( $\mathrm{Hg}$ ), Arsenic ( $\mathrm{As}$ ), Cadmium $(\mathrm{Cd})$, Cobalt $(\mathrm{Co})$, Lead $(\mathrm{Pb})$, Nickel $(\mathrm{Ni})$, Chromium $(\mathrm{Cr})$, Copper $(\mathrm{Cu})$, Zinc $(\mathrm{Zn})$ and Iron $(\mathrm{Fe})$ in water samples was done by Perkin Elmer Analyst 200 Flame Atomic Absorption Spectrophotometer (2003 model). For estimation of Arsenic and Mercury, hydride generation coupled with an atomic fluorescence detector and cold-vapor techniques was used [41]. The standard solutions were prepared by using analytical Reagent Analytical grade chemicals in acidified metal free deionised water. The calibration curves were prepared separately for all the metals, after running different concentrations of standard solutions. A reagent blank was used during the analysis and subtracted from the samples to correct for reagent impurities and other sources of errors from the environment. Average value of three replicates was taken, for each determination.

\section{RESULTS AND DISCUSSION}

The water samples collected at various sampling points from the Ulhas River flowing along the Dombivli city near Mumbai in year 2012 and 2013 were analyzed for their heavy metal content. The average analytical results are presented in Table 1.

Table 1: Concentration of heavy metals in water at various locations during the year 2012 and 2013.

\begin{tabular}{|c|c|c|c|c|c|c|c|c|c|c|c|c|}
\hline $\begin{array}{c}\text { Sampling } \\
\text { Point }\end{array}$ & Year & Season & $\begin{array}{c}\mathbf{H g} \\
(\mathrm{ppm})\end{array}$ & $\begin{array}{c}\text { As } \\
(\mathrm{ppm})\end{array}$ & $\begin{array}{c}\mathrm{Cr} \\
(\mathrm{ppm})\end{array}$ & $\begin{array}{c}\mathbf{C d} \\
(\mathrm{ppm})\end{array}$ & $\begin{array}{c}\mathrm{Pb} \\
(\mathrm{ppm})\end{array}$ & $\begin{array}{c}\mathrm{Cu} \\
(\mathrm{ppm})\end{array}$ & $\begin{array}{c}\mathbf{N i} \\
(\mathbf{p p m})\end{array}$ & $\begin{array}{c}\mathrm{Zn} \\
(\mathrm{ppm})\end{array}$ & $\begin{array}{c}\mathrm{Fe} \\
(\mathrm{ppm})\end{array}$ & $\begin{array}{c}\text { Co } \\
\text { (ppm) }\end{array}$ \\
\hline S-1 & 2012 & Rainy & 0.00 & 0.00 & 0.81 & 0.07 & 0.23 & 0.10 & 0.18 & 0.12 & 2.22 & 0.11 \\
\hline S-1 & 2012 & Winter & 0.00 & 0.00 & 0.10 & 0.10 & 0.14 & 0.12 & 0.1 & 0.16 & 5.65 & 0.08 \\
\hline S-1 & 2012 & Summer & 0.00 & 0.00 & 0.08 & 0.10 & 0.10 & 0.10 & 0.11 & 0.11 & 2.14 & 0.07 \\
\hline AVERAGE & 2012 & & 0.00 & 0.00 & 0.33 & 0.09 & 0.16 & 0.11 & 0.13 & 0.13 & 3.34 & 0.09 \\
\hline S-1 & 2013 & Rainy & 0.00 & 0.00 & 0.72 & 0.08 & 0.19 & 0.11 & 0.35 & 0.11 & 5.23 & 0.06 \\
\hline S-1 & 2013 & Winter & 0.00 & 0.00 & 0.07 & 0.10 & 0.10 & 0.13 & 0.06 & 0.15 & 6.66 & 0.10 \\
\hline S-1 & 2013 & Summer & 0.04 & 0.00 & 0.08 & 0.10 & 0.08 & 0.12 & 0.08 & 0.13 & 1.66 & 0.08 \\
\hline AVERAGE & 2013 & & 0.01 & 0.00 & 0.29 & 0.09 & 0.12 & 0.12 & 0.16 & 0.13 & 4.52 & 0.08 \\
\hline S-2 & 2012 & Rainy & 0.00 & 0.00 & 0.90 & 0.10 & 0.45 & 0.26 & 0.47 & 0.48 & 8.89 & 0.10 \\
\hline S-2 & 2012 & Winter & 0.04 & 0.00 & 0.09 & 0.08 & 0.51 & 0.38 & 0.10 & 0.78 & 12.63 & 0.13 \\
\hline S-2 & 2012 & Summer & 0.00 & 0.00 & 0.10 & 0.10 & 0.13 & 0.58 & 0.12 & 0.35 & 8.35 & 0.18 \\
\hline AVERAGE & 2012 & & 0.01 & 0.00 & 0.36 & 0.09 & 0.36 & 0.41 & 0.23 & 0.54 & 9.96 & 0.14 \\
\hline S-2 & 2013 & Rainy & 0.00 & 0.00 & 0.85 & 0.10 & 0.50 & 0.39 & 0.47 & 0.37 & 13.96 & 0.08 \\
\hline S-2 & 2013 & Winter & 0.03 & 0.00 & 0.10 & 0.07 & 0.40 & 0.59 & 0.08 & 0.63 & 15.97 & 0.11 \\
\hline S-2 & 2013 & Summer & 0.03 & 0.00 & 0.10 & 0.10 & 0.10 & 0.44 & 0.11 & 0.23 & 8.47 & 0.10 \\
\hline AVERAGE & 2013 & & 0.02 & 0.00 & 0.35 & 0.09 & 0.33 & 0.47 & 0.22 & 0.41 & 12.80 & 0.10 \\
\hline S-3 & 2012 & Rainy & 0.00 & 0.00 & 0.62 & 0.10 & 0.59 & 0.38 & 0.45 & 0.55 & 12.36 & 0.13 \\
\hline S-3 & 2012 & Winter & 0.00 & 0.00 & 0.15 & 0.09 & 0.55 & 0.74 & 0.18 & 0.71 & 15.65 & 0.18 \\
\hline S-3 & 2012 & Summer & 0.04 & 0.00 & 0.18 & 0.10 & 0.21 & 0.64 & 0.11 & 0.62 & 12.23 & 0.19 \\
\hline AVERAGE & 2012 & & 0.01 & 0.00 & 0.32 & 0.10 & 0.45 & 0.59 & 0.25 & 0.63 & 13.41 & 0.17 \\
\hline S-3 & 2013 & Rainy & 0.00 & 0.00 & 1.10 & 0.08 & 0.66 & 0.42 & 0.55 & 0.54 & 14.88 & 0.10 \\
\hline S-3 & 2013 & Winter & 0.00 & 0.00 & 0.62 & 0.10 & 0.44 & 0.98 & 0.09 & 0.80 & 17.27 & 0.36 \\
\hline S-3 & 2013 & Summer & 0.00 & 0.00 & 0.20 & 0.12 & 0.15 & 0.51 & 0.15 & 0.54 & 9.66 & 0.15 \\
\hline AVERAGE & 2013 & & 0.00 & 0.00 & 0.64 & 0.10 & 0.42 & 0.64 & 0.26 & 0.63 & 13.94 & 0.20 \\
\hline S-4 & 2012 & Rainy & 0.00 & 0.00 & 0.78 & 0.08 & 0.66 & 0.36 & 0.42 & 0.60 & 11.36 & 0.12 \\
\hline S-4 & 2012 & Winter & 0.00 & 0.00 & 0.21 & 0.09 & 0.53 & 1.12 & 0.26 & 0.66 & 15.55 & 0.19 \\
\hline S-4 & 2012 & Summer & 0.04 & 0.00 & 0.26 & 0.08 & 0.42 & 0.78 & 0.16 & 0.75 & 12.68 & 0.17 \\
\hline AVERAGE & 2012 & & 0.01 & 0.00 & 0.42 & 0.08 & 0.54 & 0.75 & 0.28 & 0.67 & 13.20 & 0.16 \\
\hline S-4 & 2013 & Rainy & 0.00 & 0.00 & 1.15 & 0.10 & 0.76 & 0.49 & 0.61 & 0.50 & 15.01 & 0.14 \\
\hline S-4 & 2013 & Winter & 0.00 & 0.00 & 0.60 & 0.12 & 0.47 & 1.20 & 0.11 & 0.95 & 16.58 & 0.18 \\
\hline S-4 & 2013 & Summer & 0.03 & 0.00 & 0.31 & 0.10 & 0.21 & 0.53 & 0.18 & 0.66 & 12.21 & 0.14 \\
\hline AVERAGE & 2013 & & 0.01 & 0.00 & 0.69 & 0.11 & 0.48 & 0.74 & 0.30 & 0.70 & 14.60 & 0.15 \\
\hline
\end{tabular}

The average values of concentration of Mercury $(\mathrm{Hg})$ and Arsenic $(\mathrm{As})$ in river water at different sampling points for year 2012 and 2013 are shown in Table 1 and the variation is represented in Figure 2. 


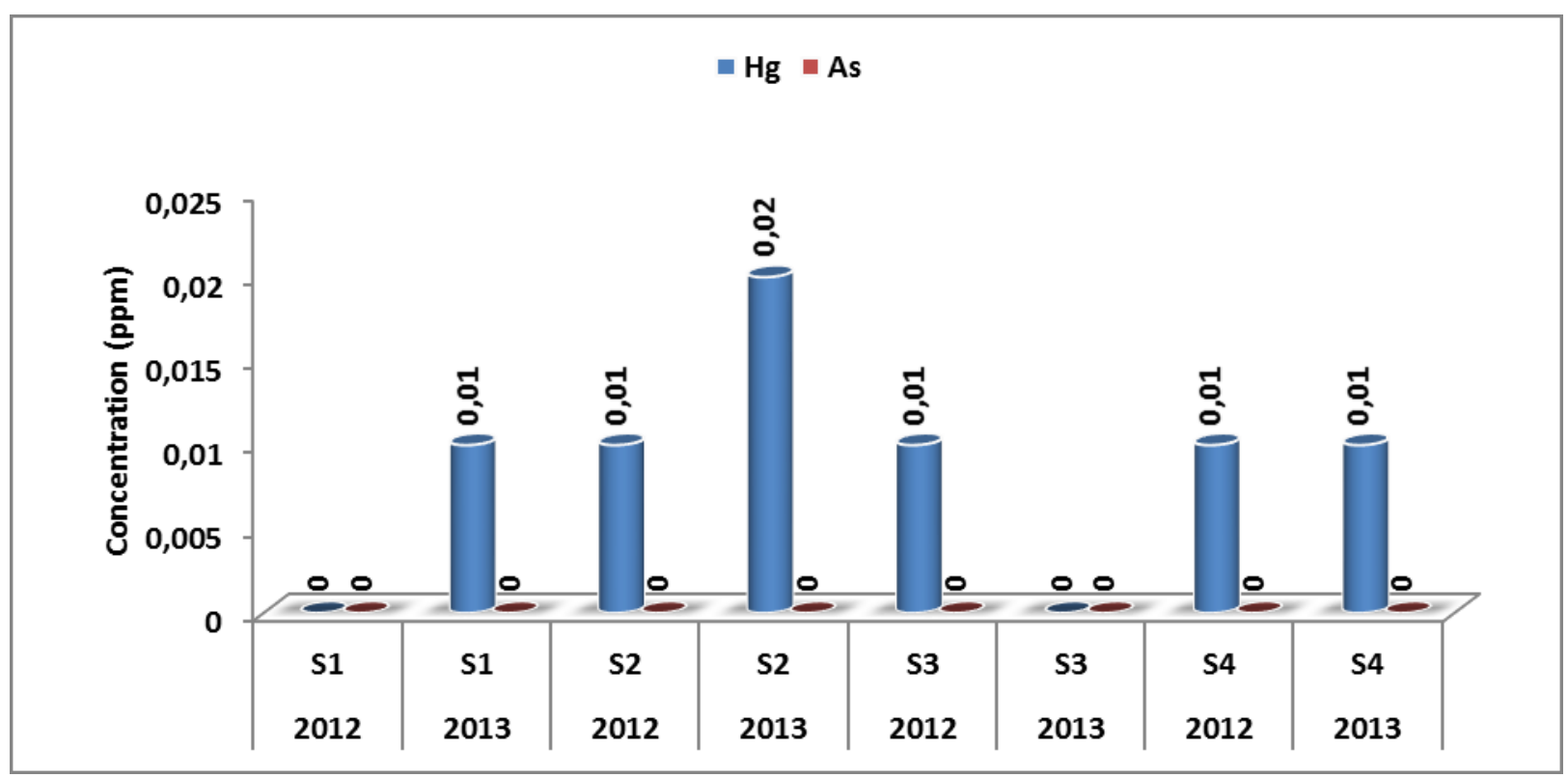

Figure 2: Variation in the average concentration of $\mathrm{Hg}$ and $\mathrm{As}$ in water at different sampling locations along Ulhas River during the year 2012 and 2013.

Arsenic (As) was not detected at any sampling points in year 2012 and 2013. The average concentration of $\mathrm{Hg}$ in 2012 at sampling points S1, S2, S3, S4 was $0.00 \mathrm{ppm}, 0.01 \mathrm{ppm}, 0.01 \mathrm{ppm}$ and $0.01 \mathrm{ppm}$ respectively. The average concentration of $\mathrm{Hg}$ in 2013 at sampling points S1, S2, S3, S4 was $0.01 \mathrm{ppm}, 0.02 \mathrm{ppm}, 0.00 \mathrm{ppm}$ and $0.01 \mathrm{ppm}$ respectively. The highest concentration of $\mathrm{Hg}$ was observed in year 2013 at sampling location S2 after the location of effluent discharge from Dombivli $M I D C$ industrial belt. $H g$ was not detected at sampling point S1 in year 2012 and S3 in year 2013. For other sampling points, the average concentration value was $0.01 \mathrm{ppm}$ during the year 2012 and 2013. As per The Environment (Protection) Rules, 1986, for Inland surface waters, the maximum limit for $H g$ is $0.01 \mathrm{mg} / \mathrm{L}$ [46]. It is important to note that the inorganic $H g$ get adsorbed to the suspended particulate matter, settles down and further gets methylated, while $\mathrm{Hg}$ in dissolved form enter the fish through the gills and ultimately enter the food chain, resulting in bioaccumulation.

The average values of concentration of Cadmium $(\mathrm{Cd})$ and Cobalt $(\mathrm{Co})$ in water at different sampling points for year 2012 and 2013 are shown in Table 1 and the variation is represented in Figure 3.

The average concentration of $C d$ in 2012 at sampling points S1, S2, S3, S4 was 0.09 ppm, $0.09 \mathrm{ppm}, 0.10 \mathrm{ppm}$ and $0.08 \mathrm{ppm}$ respectively. The average concentration of $C d$ in 2013 at sampling points S1, S2, S3, S4 was $0.09 \mathrm{ppm}, 0.09 \mathrm{ppm}, 0.10 \mathrm{ppm}$ and $0.11 \mathrm{ppm}$ respectively. Overall, the average concentration of $C d$ for year 2012 and 2013 remained almost the same. The level of $C d$ observed in our study was below the maximum limit of $2.0 \mathrm{mg} / \mathrm{L}$ set by The Environment (Protection) Rules, 1986, for Inland surface waters [46]. It is important to note here that $C d$ is similar in toxicity to lead $(\mathrm{Pb})$ and chromium $(\mathrm{Cr})$, but is less toxic to plants as compared to Copper $(\mathrm{Cu})$. It is equally toxic to invertebrates and fishes [21]. 


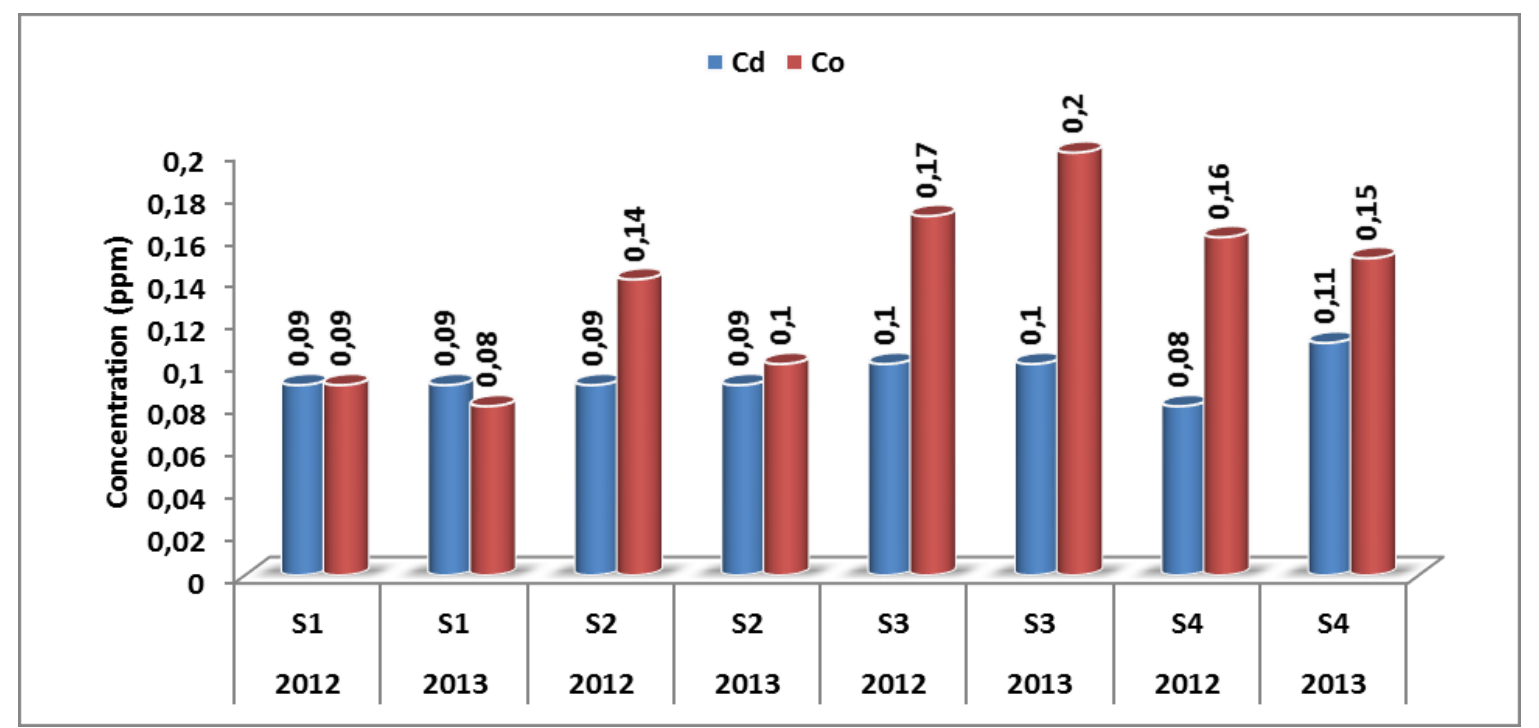

Figure 3: Variation in the average concentration of $C d$ and $C o$ in water at different sampling locations along Ulhas River during the year 2012 \& 2013.

The average concentration of Cobalt (Co) in 2012 at sampling points S1, S2, S3, S4 was 0.09 ppm, $0.14 \mathrm{ppm}, 0.17 \mathrm{ppm}$ and $0.16 \mathrm{ppm}$ respectively. The average concentration of $C o$ in 2013 at sampling points S1, S2, S3, S4 was $0.08 \mathrm{ppm}, 0.10 \mathrm{ppm}, 0.20 \mathrm{ppm}$ and $0.15 \mathrm{ppm}$ respectively. The highest concentration of $C o$ was $0.20 \mathrm{ppm}$ at sampling point S3 in year 2013. There is an increase in concentration of $C o$ in 2013 as compared to that in 2012 at samping point S3 after industrial effluent discharge location from Dombivli MIDC.

The average values of concentration of Lead $(\mathrm{Pb})$ and Nickel $(\mathrm{Ni})$ in water at different sampling points for year 2012 and 2013 are shown in Table 1 and the variation is represented in Figure 4.

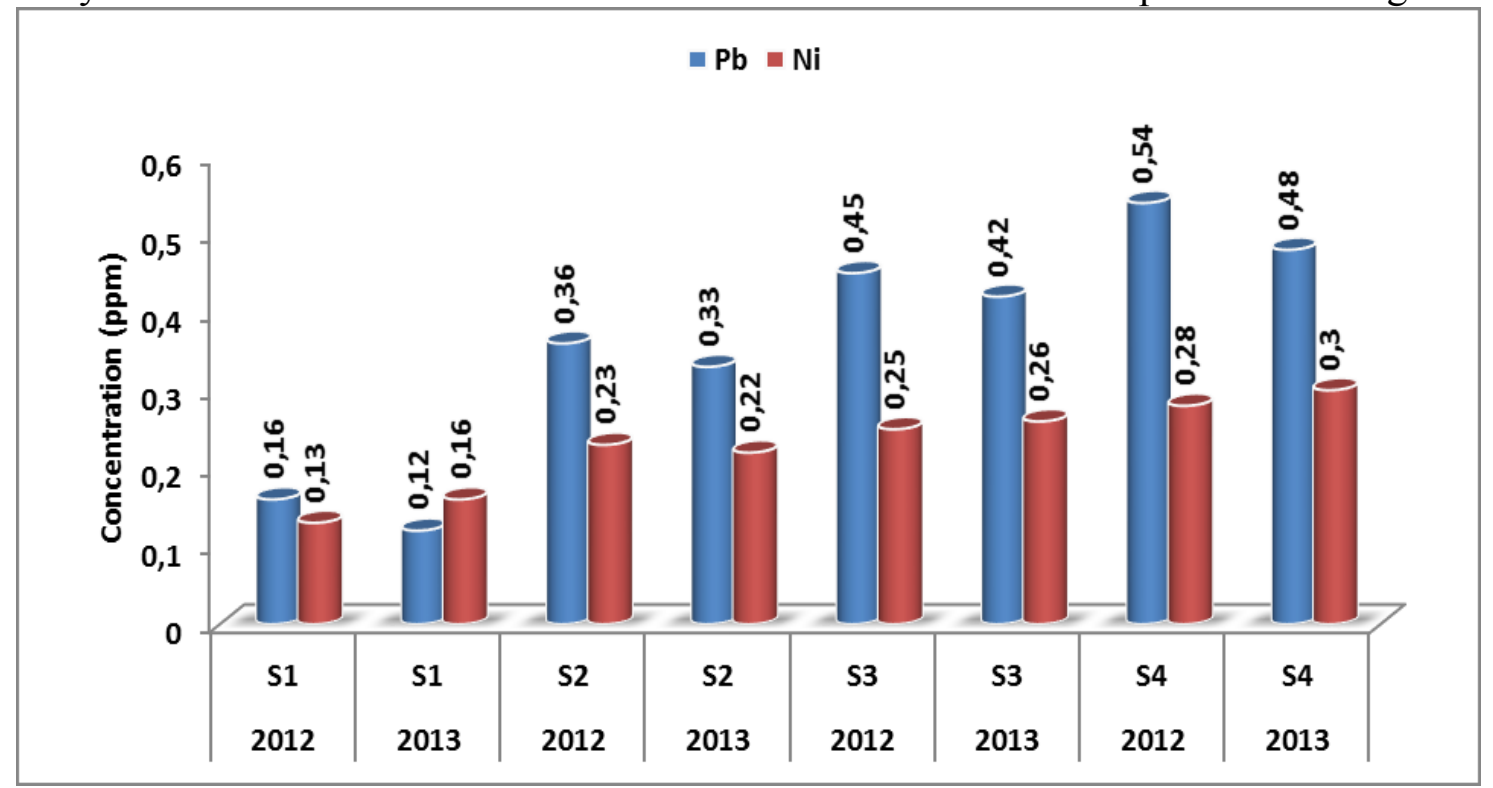

Figure 4: Variation in the average concentration of $\mathrm{Pb}$ and $\mathrm{Ni}$ in water at different sampling locations along Ulhas River during the year 2012 \& 2013.

The average concentration of $P b$ in 2012 at sampling points $\mathrm{S} 1, \mathrm{~S} 2, \mathrm{~S} 3, \mathrm{~S} 4$ was $0.16 \mathrm{ppm}, 0.36$ ppm, $0.45 \mathrm{ppm}$ and $0.54 \mathrm{ppm}$ respectively. The average concentration of $P b$ in 2013 at sampling points S1, S2, S3, S4 was $0.12 \mathrm{ppm}, 0.33 \mathrm{ppm}, 0.42 \mathrm{ppm}$, and $0.48 \mathrm{ppm}$ respectively. The trend indicates that the concentration of $P b$ in 2012 was more than that in year 2013. Though it has decreased, it was still many folds above the maximum limit of $0.1 \mathrm{mg} / \mathrm{L}$ for Inland surface waters as per The Environment (Protection) Rules, 1986 [46]. In most of chemical forms, $\mathrm{Pb}$ is toxic. It is an accumulative metabolic poison and affects the behavior, as well as the hematopoietic, vascular, 
renal, nervous and reproductive systems. It can be incorporated into the body by dermal absorption, placental transfer to the fetus ingestion and inhalation. To living organisms, $P b$ is neither essential nor beneficial. Ecological and toxicological aspects of $P b$ and its compounds in the environment have been extensively reviewed [47-52].

The average concentration of $N i$ in 2012 at sampling points S1, S2, S3, S4 was $0.13 \mathrm{ppm}, 0.23 \mathrm{ppm}$, $0.25 \mathrm{ppm}$ and $0.28 \mathrm{ppm}$ respectively. The average concentration of $N i$ in 2013 at sampling points $\mathrm{S} 1, \mathrm{~S} 2, \mathrm{~S} 3, \mathrm{~S} 4$ was $0.16 \mathrm{ppm}, 0.22 \mathrm{ppm}, 0.26 \mathrm{ppm}$ and $0.30 \mathrm{ppm}$ respectively. The values show that there is an increase in pollution of $N i$ in 2013 as compared to that in 2012. Also the values at each sampling point indicate that the concentration increases after the discharge of Dombivli MIDC industrial waste into the Ulhas River. As per The Environment (Protection) Rules, 1986, for Inland surface waters, the maximum limit for $N i$ is $3.0 \mathrm{mg} / \mathrm{L} \mathrm{[46].} \mathrm{Though} \mathrm{the} \mathrm{situation} \mathrm{may} \mathrm{not} \mathrm{be}$ alarming considering the detected concentration of $\mathrm{Ni}$ against the allowable limits, the situation has to be monitored before it crosses the same. $N i$ has the potential to accumulate in aquatic life. However its magnification along in food chain is not confirmed [53]. Long term exposure to Ni may result in liver damage, decreased body weight, and skin irritation [53]. The lethal dose low $L D L O$ of $\mathrm{Ni}$ is $12 \mathrm{mg} / \mathrm{kg}$, for rats.

The average values of concentration of Chromium (Cr), Copper $(\mathrm{Cu})$ and Zinc $(\mathrm{Zn})$ in water at different sampling points for year 2012 and 2013 are shown in Table 1 and the variation is represented in Figure 5. The average concentration of $C r$ in 2012 at sampling points S1, S2, S3, S4 was $0.33 \mathrm{ppm}, 0.36 \mathrm{ppm}, 0.32 \mathrm{ppm}$ and $0.42 \mathrm{ppm}$ respectively and that in 2013 at sampling points $\mathrm{S} 1, \mathrm{~S} 2, \mathrm{~S} 3, \mathrm{~S} 4$ was $0.29 \mathrm{ppm}, 0.35 \mathrm{ppm}, 0.64 \mathrm{ppm}$ and $0.69 \mathrm{ppm}$ respectively. The data reveals that there is an increase in $\mathrm{Cr}$ pollution each year and after the discharge of industrial effluents in the Ulhas River. The average concentration of $\mathrm{Cr}$ for year 2012 was $0.36 \mathrm{ppm}$ which increased by $36.11 \%$ to $0.49 \mathrm{ppm}$ for year 2013. As per The Environment (Protection) Rules, 1986, for Inland surface waters, the maximum limit for $C r$ is $2.0 \mathrm{mg} / \mathrm{L}$ [46]. $C r$ is a skin sensitizer and causes skin sensitizing effect. $\mathrm{Cr}$ penetrates the skin and cause painless erosive ulceration ("chrome holes") with delayed healing which commonly occurs on forearms, knuckles and fingers. The characteristic chrome sore initially forms a papule followed by forming an ulcer with raised hard edges. These ulcers can penetrate deep into soft tissue or become the sites of secondary infection which are not known to lead to malignancy $[54,55]$. Many times chromate toxicity also targets other organs such as liver and kidney, besides the intestinal tract and lungs [56].

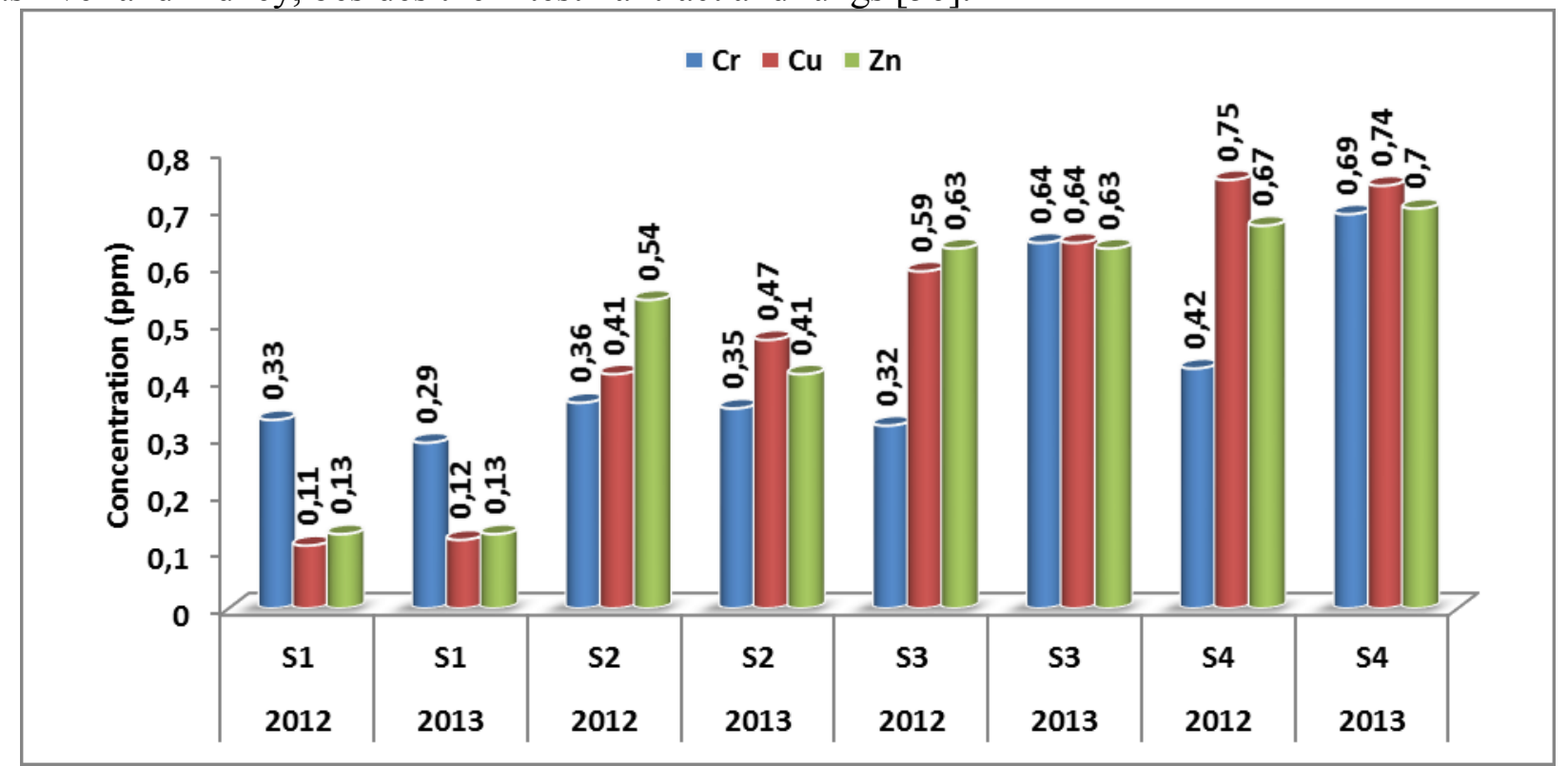

Figure 5: Variation in the average concentration of $\mathrm{Cr}, \mathrm{Cu}$ and $\mathrm{Zn}$ in water at different sampling locations along Ulhas River during the year 2012 \& 2013.

The average concentration of $C u$ in 2012 at sampling points S1, S2, S3, S4 was 0.11 ppm, $0.41 \mathrm{ppm}, 0.59 \mathrm{ppm}$ and $0.75 \mathrm{ppm}$ respectively. The average concentration of $C u$ in 2013 at 
sampling points S1, S2, S3, S4 was $0.12 \mathrm{ppm}, 0.47 \mathrm{ppm}, 0.64 \mathrm{ppm}$ and $0.74 \mathrm{ppm}$ respectively. It is observed that there is an increase in concentration of $\mathrm{Cu}$ each year and after the addition of Dombivli MIDC industrial effluents. As per The Environment (Protection) Rules, 1986, for Inland surface waters, the maximum limit for $C u$ is $3.0 \mathrm{mg} / \mathrm{L}$ [46]. Aquatic plants absorb three times more $\mathrm{Cu}$ than plants on dry lands. $\mathrm{Cu}$ is easily accumulated by plants and animals [57]. Excess $\mathrm{Cu}$ content can damage roots, by attacking the cell membrane and destroying the normal membrane structure thus inhibiting root growth and formation of numerous short, brownish secondary roots. To most fishes, aquatic plants and invertebrates copper is highly toxic. It reduces growth and rate of reproduction in plants and animals. Chronic level of $C u \mathrm{r}$ is $0.02-0.2 \mathrm{mg} / \mathrm{L}$ [21].

The average concentration of $Z n$ in 2012 at sampling points S1, S2, S3, S4 was $0.13 \mathrm{ppm}$, $0.54 \mathrm{ppm}, 0.63 \mathrm{ppm}$ and $0.67 \mathrm{ppm}$ respectively. The average concentration of $Z n$ in 2013 at sampling points S1, S2, S3, S4 was $0.13 \mathrm{ppm}, 0.41 \mathrm{ppm}, 0.63 \mathrm{ppm}$ and $0.70 \mathrm{ppm}$ respectively. The highest average concentration of $Z n$ was $0.70 \mathrm{ppm}$ in year 2013 at sampling S4. The concentration of $Z n$ increased in year 2013 as compared to 2012. In the absence of periodic monitoring and implementation of stringent norms and eventually over a long period of time, the concentration may exceed the maximum limit of $5.0 \mathrm{mg} / \mathrm{L}$ as per The Environment (Protection) Rules, 1986 for Inland surface waters [46]. Exposure to $Z n$ causes metal-fume fever with symptoms like fever, pain, fatigue, shivering, sweating. Excessive concentration of $Z n$ may result in chlorosis, necrosis and inhibits growth in plants [53].

The concentration of Iron $(\mathrm{Fe})$ in river water at different sampling points for year 2012 and 2013 are shown in Table 1 and the variation is represented in Figure 6. The average concentration of $F e$ in 2012 at sampling points S1, S2, S3, S4 was 3.34 ppm, 9.96 ppm, 13.41 ppm and $13.2 \mathrm{ppm}$ respectively, which has increased to $4.52 \mathrm{ppm}, 12.8 \mathrm{ppm}, 13.94 \mathrm{ppm}$ and $14.6 \mathrm{ppm}$ respectively in 2013. The highest average concentration of $F e$ was observed to be $14.6 \mathrm{ppm}$ in 2013 at sampling point S4. The average concentration of $F e$ for year 2012 was $9.98 \mathrm{ppm}$ which increased by $14.83 \%$ to $11.46 \mathrm{ppm}$ for year 2013. The concentration level of $\mathrm{Fe}$ reported in our study were above the limit of $3.0 \mathrm{mg} / \mathrm{L}$, as per The Environment (Protection) Rules, 1986, for Inland surface waters [46] which are of serious concern. The hazard of pathogenic organisms may increase due to the high concentration of $\mathrm{Fe}$, since most of the organisms need $\mathrm{Fe}$ for their growth [53].

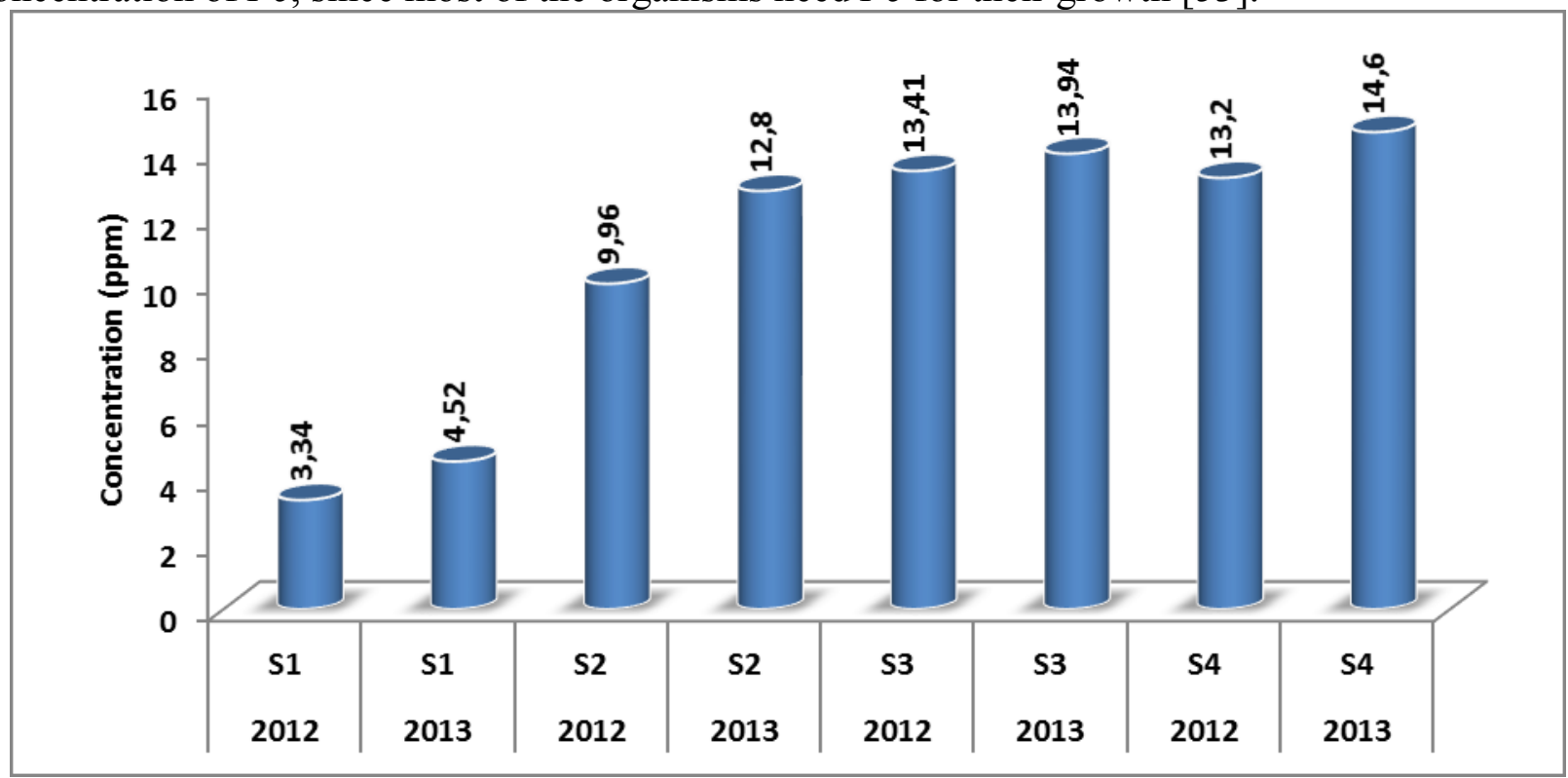

Figure 6: Variation in the average concentration of $F e$ in water at different sampling locations along Ulhas River during the year 2012 \& 2013.

\section{CONCLUSIONS}

There is an increase in discharge of effluents into the Ulhas River along the dombivli city due to the extensive industrialization. Many of the major industries have facilities for the treatment of 
generated waste. However, in the case of small scale industries, since they have lower profit margins, they do not afford huge investment for pollution control facilities. Consequently, there are sufficient evidences available related to the mismanagement of industrial wastes. Therefore, at the end of each time period the pollution problem takes menacing concern. In the present study, it is evident that the concentration of toxic heavy metals in the river water is increasing due to discharge of industrial effluent from Dombivli industrial belt Phase I and Phase II. The high concentration of heavy metals in effluent water will increase the concentration of heavy metals in the above surface water. Also, the data highlights that except Arsenic which was not detected; there is an increase in pollution, which is evident from the increasing water heavy metal concentration values in year 2013 as compared to those in year 2012. The limits of The Environment (Protection) Rules, 1986 for (Inland surface waters) are already exceeded for Lead and Iron. The present experimental data on quantification of toxic heavy metals in the water of Ulhas River along the Dombivli city will help in rational planning of pollution control strategies and their prioritization; to assess the nature and extent of pollution control needed; to evaluate effectiveness of pollution control measures already in existence. The present study of heavy metals in river water will also help to provide a means for evaluating the heavy metal contaminants in the river ecosystem of the Ulhas River.

\section{References}

[1] Zingde M.D., Govindan K., Health status of coastal waters of Mumbai and regions around. In: Environmental Problems of Coastal Areas in India (ed. Sharma, V. K.), Bookwell Publ., New Delhi, (2001) 119-132.

[2] Rajaram T., Das A., Futures, 40 (2008) 56.

[3] Khurshid S., Abdul B., Zaheeruddin, Usman S.M., Indian J.Environ.Health, 40 (1998) 45.

[4] Pachpande B.G., Ingle S.T., Orient J. Chem., 20 (2004) 117.

[5] Prabha S., Selvapathy P., Indian J. Environ. Prot., 17 (1997) 641.

[6] Singare P.U., Lokhande R.S., Pathak P.P., J. Environmental Protection, 1 (2010) 121.

[7] Singare P.U., Lokhande R.S., Pathak P.P., Interdisciplinary Environmental Review, 11 (2010) 38.

[8] Sharma R. K., Agrawal M., Marshall F.M., 'Effects of waste water irrigation on heavy metal accumulation in soil and plants', Paper presented at a National Seminar, Bangalore University, Bangalore, Abst. no. 7 (2004) 8.

[9] Ward, N. I. 'Environmental analytical chemistry' In: Fifield, F. W. and Haines, P. J. (eds.), Trace Elements, UK: Blackie Academic and Professional, (1995) 320-328.

[10] Kureshi T.W., Mesquita A.M., Sengupta R., Contrib. Mar. Sci., 60 (1987) 29.

[11] Anon., Sixth Annual Progress Report (July 1991-June 1992), Industrial Toxicology Research Centre, Lucknow, (1992) 123.

[12] Anon., Down to Earth, 12 (2003) 63.

[13] Govindsamy C., Roy Viji A.G., Jayapaul A., Int. J. Ecol. Environ. Sci., 24 (1998)141.

[14] Salomons W., Forstner U., 'Metals in the Hydrocycle', Springer-Verlag, New York, (1984) 562.

[15] Lee B.G., Griscom S.B., Lee J.S., Choi H.J., Koh C.H., Luoma S.N., Fisher N.S., Science, 287 (2000) 282.

[16] Weston D.P., Maraya K. A., Environ Toxicol Chem., 21 (2002) 962.

[17] Adams W.J., Kimerle R.A., Barnett J.W. Jr, Environ. Sci. Technol., 26 (1992) 1864.

[18] Maher W., Batley G.E., Lawrence I., Freshw Biol., 41 (1999) 361.

[19] Kennicutt M.C., Wade T.L., Presley B.J., Requejo A.G., Brooks J.M., Denoux G.J., Environ. Sci. Technol., 28 (1993) 1.

[20] Johansson J. and Rasmussen L., Bryologist, 80 (1977) 625.

[21] Moore, J.W. and Ramamoorthy, S., Heavy Metals in Natural Waters: Applied Monitoring and Impact Assessment, Springer-Verlag, New York (1984) 28-246.

[22] Singare P.U., Lokhande R.S., Naik K.U., Interdisciplinary Environmental Review, 11(2010) 90. 
[23] Maharashtra Pollution Control Board (2010-2011) 'Annual Report', 14, 24.

[24] Lokhande R.S., Singare P.U., Pimple D.S., New York Science Journal, 4 (2011) 66.

[25] Rainwater F.H., Thatchar L.L., 'Methods for Collection and Analysis of Water Samples' U.S. Geol. Surv. Water Supply Papers, 1454 (1960) 1-301.

[26] Brown E., Skougstad M.W., Fishman M.J., 'Methods for Collection and Analysis of Water Samples for Dissolved Minerals and Gases', Techniques of Water Resources Investigations of the U.S. Geological Survey, 160, Book 5, Chapter A1(1970).

[27] ICMR, Indian Council of Medical Research, Manual of Standards of Quality for Drinking Water Supplies (1975).

[28] Menon J.S., and Mahajan S.V., Our Nature, 8 (2010) 170.

[29] Rathod S.D., Patil N.N., Quadros G., Athalye R.P., 'Qualitative study of finfish and shellfish fauna of Thane creek and Ulhas River estuary', in Proc. of the National Seminar on Creeks, Estuaries and Mangroves - Pollution and Conservation, Vidya Prasarak Mandal's B.N. Bandodkar College of Science, Thane, India, 28-30 November 2002, 135 -141.

[30] Singare P.U., Dhabarde S.S., European Journal of Environmental and Safety Sciences, 2 (2014) 5.

[31] Singare P.U., Dhabarde S.S., Interdisciplinary Environmental Review, 15 (2014) 20.

[32] Singare P.U., Dhabarde S.S., International Letters of Chemistry, Physics and Astronomy, 3 (2014) 56.

[33] Singare P.U., Dhabarde S.S., International Letters of Chemistry, Physics and Astronomy, 3 (2014) 48.

[34] Singare P.U., Dhabarde S.S., International Letters of Chemistry, Physics and Astronomy, 3 (2014) 40.

[35] Singare P.U., Dhabarde S.S., International Letters of Chemistry, Physics and Astronomy, 3 (2014) 32.

[36] Singare P.U., Dhabarde S.S., International Letters of Chemistry, Physics and Astronomy, 3 (2014) 24.

[37] Singare P.U., Dhabarde S.S., International Letters of Chemistry, Physics and Astronomy, 3 (2014)16.

[38] Singare P.U., Dhabarde S.S., International Letters of Chemistry, Physics and Astronomy, 3 (2014) 8.

[39] Action Plan for Industrial Cluster "Dombivali", Maharashtra Pollution Control Board, November 2010. http://www.mpcb.gov.in

[40] Chen, M., Ma, L.Q., 'Comparison of three aqua regia digestion methods for twenty florida soils' Soil Science Society of American Journal, 65 (2001) 491.

[41] Jeffery G.H., Bassett J., Mendham J., Denny R.C., Vogel's Textbook of Quantitative Chemical Analysis, Longman Scientific \& Technical, England, $5^{\text {th }}$ Edition, (1989) 788-789.

[42] Hem J.D., 'Study and Interpretation of Chemical Characteristics of Natural Water', $3^{\text {rd }}$ edition U.S. Geological Survey, Washington (1985).

[43] American Public Health Association (APHA), 'Standard Methods for Estimation of Water and Wastewater', $19^{\text {th }}$ edition, American Water Works Association, Water environment Federation, Washington, (1995).

[44] Jackson M.L., 'Soil Chemical Analysis', New Delhi: Prentice-Hall of India Private Limited (1973).

[45] Lark B.S., Mahajan R.K., Walia T.P.S., 'Determination of metals of toxicological significance in sewage irrigated vegetables by using atomic absorption spectrometry and anodic stripping voltammetry"' Indian J. Environ. Health, 44 (2002) 164.

[46] The Environment (Protection) Rules, General Standards For Discharge Of Environmental Pollutants Part-A : Effluents [Schedule - VI] (1986) 545-548.

[47] EPA. 1985. Ambient water quality criteria for lead - 1984. U.S. Environ. Protection Agency Rep. 440/5-84-027. pp. 81 Available from Natl. Tech. Infor. Serv., 5285 Port Royal Road, Springfield, Virginia 22161. 
[48] Feierabend, J.S.,Russell, A.B., (eds.), Lead poisoning in wild waterfowl - a workshop. National Wildlife Federation, 1412 Sixteenth St. NW, Washington, D.C. (1986) 139.

[49] FWS. Use of lead shot for hunting migratory birds in the United States. Final supplemental environmental impact statement. pp. 535 Available from U.S. Fish Wildlife Service, Office of Migratory Bird Management, Washington, D.C. 20240 (1986).

[50] Lansdown, R., W. Yule (eds.). Lead toxicity. History and environmental impact, Johns Hopkins Univ. Press, Baltimore, Maryland. (1986) 286.

[51] McDonald, L.J., Can. Vet. J., 27 (1986) 131.

[52] Sanderson, G.C., Bellrose, F.C., Illinois Natural History Survey, Spec. Publ. (SP-04) (1986) 1.

[53] Tiwana, N.S., Jerath, N., Singh, G., Ravleen, M. (Eds.) 'Heavy metal pollution in Punjab Rivers', in Newsletter Environmental Information System (ENVIS), Punjab State Council for Science and Technology, India, Vol. 3, No. 1, (2005) 3-7.

[54] Geller, R., "Chromium." In: Clinical Environmental Health and Toxic Exposures. Sullivan, J.B., Jr. and Krieger, G.R., editors. $2^{\text {nd }}$ Ed. Lippincott Williams \& Wilkins, Philadelphia, PA (2001).

[55] Meditext - Medical Management, "Chromium Hexavalent Salts." TOMES Information System. Denver, CO: Micromedex, Inc (2005).

[56] Rom, W. N., Environmental and Occupational Medicine. $4^{\text {th }}$ Ed. by Lippincott Williams \& Wilkins (2007).

[57] Centre for Ecological Sciences, IIS (2001) 'Environmental hand book - documentation on monitoring and evaluating environmental impacts', Compendium of Environmental Standards, Vol. III, Indian Institute of Science, Bangalore, available at http://wgbis.ces.iisc.ernet.in/energy/HC270799/HDL/ENV/enven/vol329.htm\#copper (accessed on 03/05/2015) 